\title{
STUDY OF THE TENDENCY TO EDEMA FORMATION ASSOCIATED WITH INCOMPETENCE OF THE VALVES OF THE COMMUNI- CATING VEINS OF THE LEG. OXYGEN TENSION OF THE BLOOD CONTAINED IN VARICOSE VEINS
}

\author{
By H. E. HOLLING, 1 H. K. BEECHER, AND R. R. LINTON \\ (From the Surgical Laboratories of the Harvard Medical School at the Massachusetts \\ General Hospital, Boston)
}

(Received for publication March 25, 1938)

The complications of varicose veins are well known, but the etiology of these complications has never been satisfactorily explained. Many more or less plausible statements as to the causes of varicose ulcer, for example, have been offered. One of the most persistent concepts has been that the incompetence of the valves of the leg veins is followed by venous stagnation, and venous stagnation by anoxia of the region; this renders the tissues more susceptible to trauma and ulceration. The question remains, why do ulcers develop in one case but not in another? Evidently several factors are involved. This study was designed to add objective information regarding alterations of physiological processes which may be responsible for the complications associated with varicose veins.

deTakáts and his coworkers (1) and Blalock (2) have studied the oxygen tension of the blood found in varicose veins, to obtain data concerning the pathology associated with these abnormal veins. deTakáts found the oxygen content distinctly lower in varicose veins of the leg than in the antecubital veins of the arm. This is hardly a fair comparison. Blalock found ". . . in nine of the ten cases observed, the oxygen content of the blood from the femoral veins was higher on the diseased side . . . than on the opposite side." He stated, "No definite relationship seems to hold between the oxygen content of the blood of the dilated veins of the lower part of the leg and similarly located normal veins of the opposite leg. ..."

We questioned this latter statement and expected to find on examining the blood a greatly lowered oxygen content in the varicose veins. We must admit at once that no significant lowering of the oxygen content was found when analyses of blood from varicose veins with and without ul-

\footnotetext{
${ }^{1}$ Fellow of the British Medical Research Council.
}

ceration were compared with analyses of blood from similarly situated normal veins. When ulcers were present, blood was usually withdrawn from the vein draining the ulcer. It was taken under oil. Heparin was used as the anticoagulant. The blood was aspirated in as small quantity as was consistent with careful analysis (not more than $3 \mathrm{cc}$.). Small quantities are important to avoid the possibility of withdrawing blood contained in the deep veins, where presumably the oxygen content would be higher.

The oxygen content and the total oxygen combining power were determined in duplicate by the method of Van Slyke and Neil (3), and from these results, the oxygen tension of the blood was calculated from the data of Henderson, Bock, et al. (4). These data are presented in Tables II, III, and IV.

The failure to find evidence of hypo-oxygenation of the blood in varicose veins was unexpected, and it was thought that rest in bed might have had a temporarily beneficial effect on the venous circulation of the legs. This was disproved by taking blood from the varicose veins of ambulatory patients in the Outpatient Clinic and comparing the oxygen content with that of blood from normal leg veins under similar circumstances.

Superficially, it would seem that the major premise of the explanation outlined above regarding the cause of varicose ulcers had been destroyed by Blalock's observations supported by our work. Actually, it must be kept in mind that the oxygen content of the blood in the large veins may not give a true representation of the capillary oxygen content. One uncontrolled factor here is the possibility of a shunt of blood directly from the arterioles to venules, largely avoiding some regions of the capillary bed. Furthermore, pressure from edema of the skin would seriously impair the local capillary circulation there. Accordingly, we were 
led direotly to a study of edema formation in cases of varicose veins with and without ulcer formation.

\section{Measurement of edema formation}

In order to measure the amount of tissue fluid formed in the legs, the patient was taken from bed and seated for 2 hours with his foot in a dependent position. The increase in volume of his leg, after the circulation had become stabilized, was taken as a measure of the amount of tissue fluid formed.

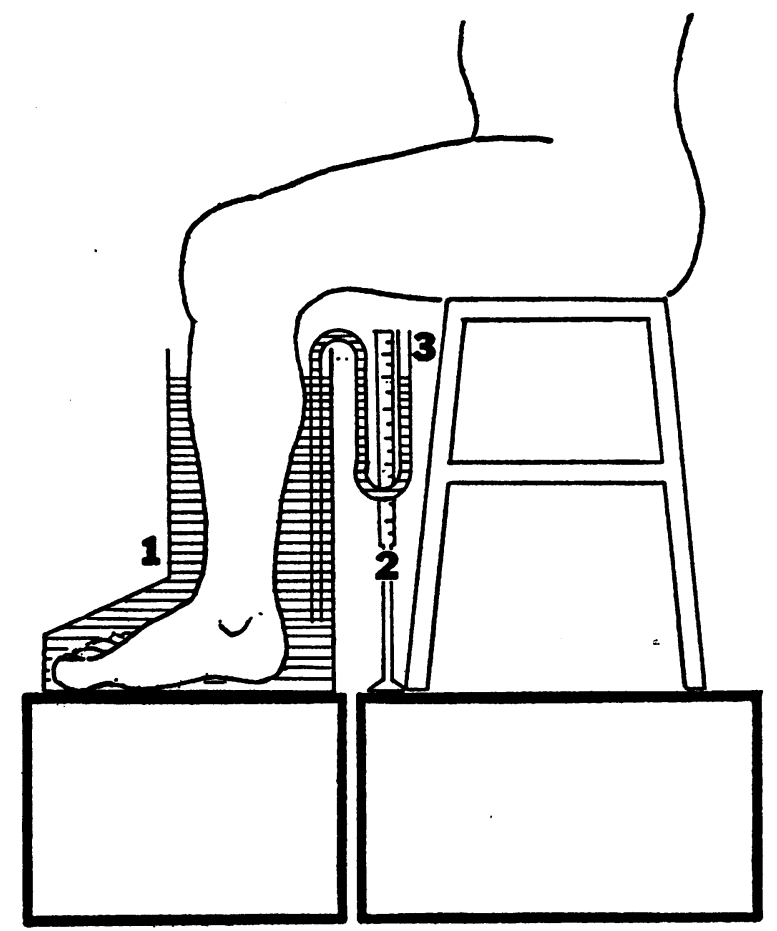

FIG. 1

\section{Apparatus for Measuring the Volume of Tissue Fluid Formed During Test}

To measure the leg volume a boot-shaped plethysmograph of 9 liters capacity was made from reinforced copper sheet. This was insulated with felt and plaster bandage. When the leg was placed in the boot care was taken that the circulation should not be obstructed by clothing, by pressure of the sides of the plethysmograph, or by the chair edge. With the foot in position, 5 liters of water at 86 to $90^{\circ} \mathrm{F}$. were poured into the boot. After allowing 10 minutes for the relaxation of the arterioles, veins, and smaller vessels (5) the height of the water in the plethysmograph was measured. The most satisfactory method was found to be by the use of a siphon and U-tube manometer arranged as shown in Figure 1. The volume of the leg was measured by water displacement. Then all of the water was siphoned off, so that the hydrostatic pressure of the water on the leg should not hinder the formation of edema during the observation period.

The plethysmograph was placed on a separate platform so that it could be lowered from the leg, emptied, and the leg dried gently without moving it. This prevented emptying of the veins by leg movement.

At the end of 2 hours, 5 liters of water at the same temperature as that used at the beginning of the experiment were poured into the boot. As a result of the transudation of fluid from the blood stream into the tissues, the leg volume was increased and the water rose to a height greater than the initial level. Water was removed until the original level was regained. That removed was measured. Its volume represents the quantity of edema fluid which was formed during the sitting period, and is expressed as cubic centimeters of tissue fluid per $100 \mathrm{cc}$. leg volume. It is important to have the foot and leg in exactly the same position for each of the two determinations.

The accuracy of using the manometer as a measure of the height of the fluid in the boot was tested by adding measured amounts of water to that in the boot and then measuring the volume of water it was necessary to remove to bring the manometer reading back to the previous level. The actual amount of water added was not known by the observer. The results given in Table I show that the error was small enough to make significant the changes in volume found.

TABLE I

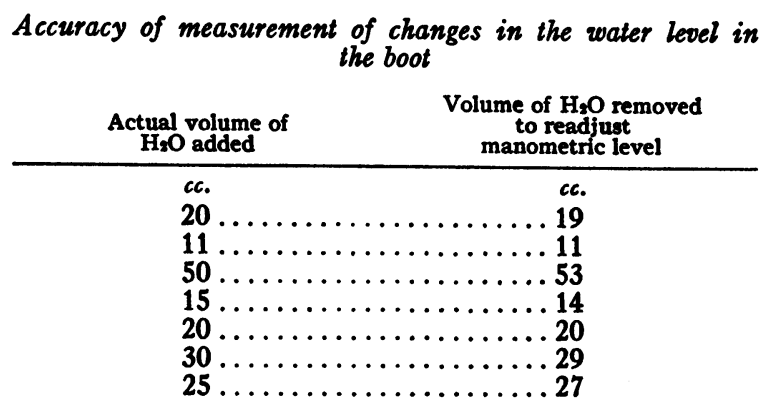

RESULTS

The detailed results obtained in the study of edema formation in these cases are shown in the tables. The amount of tissue fluid formed in 2 hours in the legs of 4 normal individuals was $3.9 \pm 0.7 \mathrm{cc}$. per $100 \mathrm{cc}$. leg volume.

Six patients having varicose veins without ulceration showed an edema formation in 2 hours of $6.0 \pm 0.7 \mathrm{cc}$. per $100 \mathrm{cc}$. leg volume.

Five patients having varicose veins with ulceration showed an average edema formation of 6.5 $\pm 0.6 \mathrm{cc}$. per $100 \mathrm{cc}$. leg volume.

It is important to make a series of such studies at the same time of year if they are to be com- 
TABLE II

Normal subjects

\begin{tabular}{|c|c|c|c|c|c|c|c|c|c|}
\hline Patient & Sex & Age & $\begin{array}{c}\text { Amount } \\
\text { of edema } \\
\text { per } 100 \mathrm{cc} . \\
\text { legt }\end{array}$ & $\begin{array}{l}\text { Blood } \\
\text { oxygen } \\
\text { before } \\
\text { and after } \\
\text { sitting }\end{array}$ & $\begin{array}{c}\text { Blood } \\
\text { oxygen } \\
\text { at } \\
\text { saturation }\end{array}$ & $\begin{array}{c}\text { Oxygen } \\
\text { saturation }\end{array}$ & $\begin{array}{c}\mathrm{CO}_{2} \\
\text { volume }\end{array}$ & $\begin{array}{l}\text { Oxygen } \\
\text { tension }\end{array}$ & $\begin{array}{l}\text { Comment. (Patients sitting unless } \\
\text { otherwise specified) }\end{array}$ \\
\hline M. M...... & $\mathbf{M}$ & $\begin{array}{c}\text { years } \\
50\end{array}$ & $\begin{array}{l}c c . \\
5.5\end{array}$ & $\begin{array}{l}c c . \text { per } \\
100 c c . \\
8.5 \\
12.4\end{array}$ & $\begin{array}{l}c c . \text { per } \\
100 \text { cc. } \\
19.0 \\
22.8\end{array}$ & $\begin{array}{l}\text { per cent } \\
45.0 \\
54.5\end{array}$ & $\begin{array}{c}\text { per cent } \\
58.8 \\
53.5\end{array}$ & $\begin{array}{c}\mathrm{mm} . \mathrm{Hg} \\
25.3 \\
29.6\end{array}$ & $\begin{array}{l}\text { No abnormality of circulation } \\
\text { of the legs }\end{array}$ \\
\hline B. T........ & $\mathbf{M}$ & 50 & 3.3 & $\begin{aligned} 13.4 \\
9.3\end{aligned}$ & $\begin{array}{l}19.2 \\
19.7\end{array}$ & $\begin{array}{l}69.0 \\
47.4\end{array}$ & $\begin{array}{l}60.5 \\
64.0\end{array}$ & $\begin{array}{l}39.5 \\
28.2\end{array}$ & $\begin{array}{l}\text { No abnormality of circulation } \\
\text { of the legs }\end{array}$ \\
\hline H. E. H. . & $\mathbf{M}$ & 28 & 2.2 & $\begin{array}{l}15.9 \\
16.2\end{array}$ & $\begin{array}{l}18.1 \\
19.9\end{array}$ & $\begin{array}{l}87.5 \\
81.3\end{array}$ & $\begin{array}{l}51.0 \\
50.7\end{array}$ & $\begin{array}{l}\mathbf{5 4 . 5} \\
\mathbf{4 7 . 0}\end{array}$ & $\begin{array}{l}\text { No abnormality of circulation } \\
\text { of the legs }\end{array}$ \\
\hline H. E. H. . & $\mathbf{M}$ & 28 & $(4.4)^{*}$ & $\begin{array}{l}13.8 \\
16.2\end{array}$ & $\begin{array}{l}19.9 \\
22.0\end{array}$ & $\begin{array}{l}69.5 \\
73.5\end{array}$ & $\begin{array}{l}56.0 \\
46.0\end{array}$ & $\begin{array}{l}38.4 \\
39.0\end{array}$ & $\begin{array}{l}\text { No abnormality of circulation } \\
\text { of the legs (standing) }\end{array}$ \\
\hline C. S. . & $\mathbf{M}$ & 19 & 4.6 & $\begin{array}{l}18.6 \\
16.1\end{array}$ & $\begin{array}{l}22.2 \\
22.9\end{array}$ & $\begin{array}{l}83.9 \\
70.2\end{array}$ & $\begin{array}{l}50.3 \\
52.5\end{array}$ & $\begin{array}{l}49.0 \\
38.3\end{array}$ & $\begin{array}{l}\text { Tendency to acrocyanosis shown } \\
\text { in feet, circulation of leg other- } \\
\text { wise normal }\end{array}$ \\
\hline
\end{tabular}

* Not included in the mean because subject was standing.

$\dagger$ The standard deviation of the mean for the edema fluid is $3.9 \pm 0.7$.

pared, for studies made in hot weather are not comparable to others made in cool weather.

The above results show a barely significant increase in the formation of tissue fluid in the legs in which simple varicose veins are present, for the difference of the means is a little more than twice the square root of the sum of the squares of the standard deviations. There is no significant increase in the formation of edema fluid in the patients having ulceration with their varicose veins over the varicose group not having ulceration.

The communicating veins are the vessels which connect the superficial and deep systems of the leg veins. In the normal leg the valves of the communicating veins above the ankle are arranged so as to permit the flow of blood inward. The incompetence of the valves of these veins can be demonstrated (Trendelenburg) if the leg is first elevated to empty the veins and a venous tourniquet then applied below the knee. When the leg is allowed to become dependent, the superficial veins fill rapidly from the deep veins if the valves of the communicating veins are incompetent. If the valves in the communicating veins are competent the superficial veins fill slowly by the venous return from the foot, but rapidly from the incompetent saphenous system as soon as the tourniquet is released.

All the cases of varicose ulcer which we ex- amined in this series showed incompetence of the valves of the communicating veins. Occasionally (Table III) incompetence of the valves of the communicating veins was found in the group without ulcer.

When the subjects are divided into two groups on the basis of whether the valves of their communicating veins are competent (normals plus those with simple varicosities of the great saphenous system) and those in whom the valves of the communicating veins are incompetent, a highly significant increase in the formation of edema fluid is found in the latter group.

The following subjects fall into the first group: Subjects M. M., B. T., H. E. H., C. S., M. E. W., M. F., and W. L. The edema fluid formed per $100 \mathrm{cc}$. leg volume in 2 hours of sitting is 4.1 $\pm 0.4 \mathrm{cc}$.

These subjects fall into the latter group: Subjects M. M. L., M. C., C. J. B., M. K., B. M., E. M., E. C. S., and B. E. F. The edema fluid formed per $100 \mathrm{cc}$. leg volume in 2 hours of sitting is $6.9 \pm 0.4 \mathrm{cc}$.

The difference of the means here is 5 times the square root of the sum of the squares of the standard deviations of the mean; accordingly, the data are highly significant.

We can say, therefore, that the rate of edema formation in cases of varicose veins appears to 
TABLE III

Varicose veins without ulceration

\begin{tabular}{|c|c|c|c|c|c|c|c|c|c|}
\hline Patient & Sex & Age & $\begin{array}{c}\text { Amount } \\
\text { of edema } \\
\text { per } 100 \mathrm{cc} . \\
\text { leg } \ddagger\end{array}$ & $\begin{array}{l}\text { Blood } \\
\text { oxygen } \\
\text { before } \\
\text { and after } \\
\text { gitting }\end{array}$ & $\begin{array}{c}\text { Blood } \\
\text { oxygen } \\
\text { at } \\
\text { saturation }\end{array}$ & $\begin{array}{c}\text { Oxygen } \\
\text { saturation }\end{array}$ & $\begin{array}{c}\mathrm{CO}_{2} \\
\text { volume }\end{array}$ & $\begin{array}{l}\text { Oxygen } \\
\text { tension }\end{array}$ & $\begin{array}{l}\text { Comment. (Patients sitting unless } \\
\text { otherwise specified) }\end{array}$ \\
\hline M. E. W. . & $F$ & $\begin{array}{c}\text { years } \\
42\end{array}$ & $\begin{array}{l}c c . \\
4.4\end{array}$ & $\begin{array}{l}c c . \text { per } \\
100 \text { cc. } \\
13.6 \\
13.3\end{array}$ & $\begin{array}{l}c c . \text { per } \\
100 c c . \\
22.0\end{array}$ & $\begin{array}{l}\text { per cent } \\
60.5\end{array}$ & $\begin{array}{l}\text { per cent } \\
45.0 \\
47.8\end{array}$ & $\begin{array}{l}m m . H g \\
46.0 \\
37.7\end{array}$ & $\begin{array}{l}\text { Feet swollen at night. Long } \\
\text { and short saphenous affected }\end{array}$ \\
\hline M. F. . & $\mathbf{M}$ & 63 & 4.9 & $\begin{aligned} 11.0 \\
9.6\end{aligned}$ & $\begin{array}{l}21.0 \\
22.9\end{array}$ & $\begin{array}{l}52.5 \\
42.0\end{array}$ & $\begin{array}{l}61.5 \\
57.3\end{array}$ & $\begin{array}{l}30.4 \\
24.0\end{array}$ & $\begin{array}{l}\text { Hypertension. Saphenous af- } \\
\text { fected. Had ulcers previously }\end{array}$ \\
\hline W. L.. & $\mathbf{M}$ & 34 & 4.1 & $\begin{array}{l}19.4 \\
12.6\end{array}$ & $\begin{array}{l}23.4 \\
24.5\end{array}$ & $\begin{array}{l}83.0 \\
51.5\end{array}$ & $\begin{array}{l}49.0 \\
52.0\end{array}$ & $\begin{array}{l}48.0 \\
28.0\end{array}$ & Saphenous vein only affected \\
\hline M. M. L... & $\mathbf{F}$ & 38 & 7.0 & $\begin{array}{l}13.0 \\
14.0\end{array}$ & $\begin{array}{l}18.4 \\
19.1\end{array}$ & $\begin{array}{l}70.5 \\
73.0\end{array}$ & $\begin{array}{l}50.0 \\
47.0\end{array}$ & $\begin{array}{l}38.0 \\
39.0\end{array}$ & $\begin{array}{l}\text { History of phlebitis. Feet swell } \\
\text { towards night. Saphenous and } \\
\text { communicating veins incom- } \\
\text { petent }\end{array}$ \\
\hline M. C.. & $\mathrm{F}$ & 49 & $8.1^{*}$ & $\begin{array}{l}15.8 \\
10.4\end{array}$ & $\begin{array}{l}19.3 \\
19.8\end{array}$ & $\begin{array}{l}82.0 \\
52.2\end{array}$ & $\begin{array}{l}49.0 \\
49.0\end{array}$ & $\begin{array}{l}46.8 \\
27.5\end{array}$ & $\begin{array}{l}\text { Previous ulcer. Saphenous and } \\
\text { communicating veins incom- } \\
\text { petent }\end{array}$ \\
\hline C. J. B... & M & 47 & $7.6 *$ & $\begin{array}{l}14.8 \\
12.4\end{array}$ & $\begin{array}{l}19.6 \\
21.1\end{array}$ & $\begin{array}{l}75.5 \\
58.8\end{array}$ & $\begin{array}{l}52.5 \\
51.5\end{array}$ & $\begin{array}{l}42.0 \\
31.5\end{array}$ & $\begin{array}{l}\text { Saphenous and communicating } \\
\text { veins incompetent }\end{array}$ \\
\hline W. J. H. . & $\mathbf{M}$ & 51 & $(5.4) \dagger$ & $\begin{array}{r}11.5 \\
8.6\end{array}$ & $\begin{array}{l}18.1 \\
20.5\end{array}$ & $\begin{array}{l}63.5 \\
42.0\end{array}$ & $\begin{array}{l}59.0 \\
58.0\end{array}$ & $\begin{array}{l}35.2 \\
24.2\end{array}$ & $\begin{array}{l}\text { Saphenous only affected (Stand- } \\
\text { ing) }\end{array}$ \\
\hline
\end{tabular}

* Pitting edema.

$\dagger$ Not included in the mean because subject was standing.

\$ The standard deviation of the mean for the edema fluid is $6.0 \pm 0.7$.

be increased only slightly above normal, unless the valves of the communicating veins are incompetent. When this is the case the edema formation is greatly increased.

It has already been pointed out that we were unable to demonstrate any truly significant differences as far as oxygen tension was concerned in the three groups: normal, simple varicose, and varicose veins with ulceration. Furthermore, we have been unable to demonstrate any significant difference in oxygen tension when the data are divided on the basis of competent or incompetent communicating veins. Neither were we able to correlate significantly the oxygen tension with edema formation in any of these cases.

\section{DISCUSSION}

The results demonstrate in individuals having simple varicosities of the great saphenous system of veins, that the rate of edema formation in the dependent leg is slightly but definitely increased over the rate found under the same conditions in normal subjects. Furthermore, when the valves of the communicating veins are incompetent a much greater tendency to edema formation exists than is the case when these valves are normal.

According to Blalock's data and our data, a diminished oxygen tension of the blood is not a factor in either this phenomenon or in the development of varicose ulcers. These oxygen studies are concerned of course with venous, not capillary blood. As already pointed out, this may not give an index of the oxygen tension in a particular part of the capillary bed. It is possible that the blood may be shunted around the edematous regions where the tissue tension is relatively high, the major portion of the blood tending to flow through less obstructed channels, or the blood may be diverted directly from arteriole to venule, avoiding the capillary bed. In any case, the venous blood may not give a fair representation of the oxygen tension in certain parts of the capillary system. Studies of the saphenous blood offer no explanation of the increased tendency to edema formation described above.

Failure of blood analysis to explain the findings 
TABLE IV

Varicose veins with ulceration

\begin{tabular}{|c|c|c|c|c|c|c|c|c|c|}
\hline Patient & Sex & Age & $\begin{array}{l}\text { Amount } \\
\text { of edema } \\
\text { per } 100 \mathrm{cc} . \\
\text { leg } \ddagger\end{array}$ & $\begin{array}{l}\text { Blood } \\
\text { oxygen } \\
\text { before } \\
\text { and after } \\
\text { sitting }\end{array}$ & $\begin{array}{c}\begin{array}{c}\text { Blood } \\
\text { oxygen } \\
\text { at } \\
\text { saturation }\end{array} \\
\end{array}$ & $\begin{array}{c}\text { Oxygen } \\
\text { saturation }\end{array}$ & $\begin{array}{c}\mathrm{CO}_{2} \\
\text { volume }\end{array}$ & $\begin{array}{c}\text { Oxygen } \\
\text { tension }\end{array}$ & $\begin{array}{l}\text { Comment. (Patients sitting unless } \\
\text { otherwise specified) }\end{array}$ \\
\hline M. K. . . . . & $\mathbf{M}$ & $\begin{array}{c}\text { years } \\
48\end{array}$ & $\begin{array}{c}c c . \\
\text { *Before } \\
\text { test } \\
5.6\end{array}$ & $\begin{array}{l}c c . \text { per } \\
100 \text { cc. } \\
15.1 \\
13.2\end{array}$ & $\begin{array}{l}\text { ce. per } \\
100 \text { cc. } \\
20.7 \\
22.0\end{array}$ & $\begin{array}{l}\text { per cent } \\
72.8 \\
59.5\end{array}$ & $\begin{array}{l}\text { per cent } \\
\\
50.6 \\
51.5\end{array}$ & $m m . H g$ & $\begin{array}{l}\text { Ankles swell. Saphenous and } \\
\text { communicating veins incompe- } \\
\text { tent. Ulcer at ankle }\end{array}$ \\
\hline B. M........ & F & 46 & $\begin{array}{l}\text { *Before } \\
\text { test } \\
7.4\end{array}$ & $\begin{array}{l}9.3 \\
9.3\end{array}$ & $\begin{array}{l}18.1 \\
19.3\end{array}$ & $\begin{array}{l}51.0 \\
47.5\end{array}$ & $\begin{array}{l}56.0 \\
54.0\end{array}$ & $\begin{array}{l}28.2 \\
26.2\end{array}$ & $\begin{array}{l}\text { Saphenous and communicating } \\
\text { veins affected }\end{array}$ \\
\hline E. M........ & F & 45 & 5.4 & $\begin{array}{r}12.9 \\
5.6\end{array}$ & $\begin{array}{l}17.2 \\
19.6\end{array}$ & $\begin{array}{l}75.0 \\
28.6\end{array}$ & 36.0 & 37.6 & $\begin{array}{l}\text { Ulcer } 2 \mathrm{~cm} \text {. diameter. Com- } \\
\text { municating and saphenous veins } \\
\text { incompetent }\end{array}$ \\
\hline W. K........ & $\bar{M}$ & 26 & $(5.2) \dagger$ & $\begin{array}{l}18.2 \\
19.3\end{array}$ & $\begin{array}{l}21.5 \\
22.4\end{array}$ & $\begin{array}{l}85.0 \\
86.5\end{array}$ & $\begin{array}{l}47.1 \\
44.5\end{array}$ & $\begin{array}{l}49.6 \\
51.0\end{array}$ & $\begin{array}{l}\text { Probably arteriovenous anas- } \\
\text { tomosis. Therefore not used in } \\
\text { average of incompetent com- } \\
\text { municating veins. Communi- } \\
\text { cating veins incompetent }\end{array}$ \\
\hline E. C. S... & F & 37 & 5.4 & $\begin{array}{l}14.7 \\
11.7\end{array}$ & $\begin{array}{l}21.9 \\
22.2\end{array}$ & $\begin{array}{l}67.0 \\
53.0\end{array}$ & $\begin{array}{l}51.0 \\
48.0\end{array}$ & $\begin{array}{l}36.0 \\
27.8\end{array}$ & $\begin{array}{l}\text { Communicating veins incompe- } \\
\text { tent. Preulcerous condition }\end{array}$ \\
\hline B. E. F...... & F & 42 & $8.5^{*}$ & $\begin{array}{l}13.5 \\
10.3\end{array}$ & $\begin{array}{l}21.0 \\
21.8\end{array}$ & $\begin{array}{l}64.0 \\
47.5\end{array}$ & $\begin{array}{l}47.0 \\
47.0\end{array}$ & $\begin{array}{l}33.0 \\
24.8\end{array}$ & $\begin{array}{l}\text { Communicating veins incompe- } \\
\text { tent }\end{array}$ \\
\hline
\end{tabular}

* Pitting edema.

+ Not included in the mean because of question of arteriovenous anastomosis.

$\mp$ The standard deviation of the mean for the edema fluid is $6.5 \pm 0.6$.

raises several questions. First, why should incompetence of the valves of the communicating veins be associated with increased edema formation? Two answers to this question are possible. The valves of the communicating veins are found incompetent in most cases following deep phlebitis. As a consequence of this condition it is probably true that the valves of the deep veins are also incompetent following their recanalization (6). If the valves of the deep veins are incompetent, these veins of the lower leg would be subjected to sustained high pressures. These pressures during relaxation of the leg muscles would be hydrostatic, that is, dependent approximately upon the weight of the column of blood from the heart level to the level of the lower leg.

At all times, with the patient in the upright position, the pressure in the veins would then be far above the colloid osmotic pressure of the blood even during walking. (See Beecher, Field, and Krogh (7).) The condition in the extensive deep system of veins would be comparable to that described by Beecher (8) for simple varicosities of the superficial veins. Sustained high pressure in the superficial veins alone was not found associated with gross edema formation, presumably because the lymphatics were adequate to drain the relatively limited tissues drained by these veins. But now, if the deep system of veins is exposed to a sustained high venous pressure this should greatly increase the quantity of tissue fluid formed during relaxation of muscles. (According to Wells (9), the intramuscular pressures during contraction may be great enough to prevent this filtration.) With incompetent valves of the communicating veins, this high pressure would be transmitted to the superficial system where presumably the valves of the saphenous system would also be inadequate and the pressure there already high. It seems reasonable to suppose with sustained high pressures throughout the venous system of the leg that a greater quantity of tissue 
fluid would be formed than when the superficial system alone was involved, and it is not surprising that the lymphatics are inadequate to transport away this greatly increased accumulation of tissue fluid. Edema develops.

Presumably, if these patients sat absolutely still with legs completely relaxed at all times the rate of formation of tissue fluid would be equally great in subjects with normal veins and those with incompetent valves, insofar as a sustained venous pressure is a factor in the development of edema. Practically, these patients were not trained subjects and evidently moved around enough to prevent sustained high venous pressures from developing when the venous valves were competent. In the ordinary conditions of life, of course, the difference between the normals and the group with inadequate venous valves would be exaggerated, and one would expect to find relatively far more edema fluid formed in the latter group.

Another answer to the question raised above might be that the phlebitis which damaged the valves of the communicating veins may have damaged the lymphatic drainage system as well. Drinker (10) has suggested that the lymphatics may be "varicose." Impairment of the lymphatic apparatus occurring together with the increased production of tissue fluid postulated above would be very effective in producing edema. It seems likely that in certain cases both of these effects operate to produce edema. A further condition tending to produce stagnation of lymph would be the limitation of movement when the edema became great enough to produce discomfort.

Inadequacy of the lymphatic system of the extremity, from whatever cause, would be followed by edema of the lower leg and the preparation of a fertile field for the development of infection as Drinker's work (11) has shown. Possibly the patient with incompetent valves of the communicating veins should be considered to be in a prevaricose ulcer condition. The development of low grade infection is of considerable importance in the production and extension of varicose ulcers. The rôle of fungus infection here has been inadequately studied to date.

\section{SUMMARY}

We have measured the oxygen tension of the blood found in varices of the great saphenous sys- tem with and without ulceration. Our data confirm Blalock in that we did not find low oxygen tensions to be present in these cases. It is pointed out that study of saphenous blood may not provide a true index of the oxygen tension in certain parts of the capillary bed.

The volume of edema fluid formed in three classes of subjects has been measured in the lower leg during a sitting period: normals, cases with simple varicosities, and cases in which the varicosities were complicated by ulcer formation.

A barely significant increase above normal occurs in the formation of tissue fluid when simple varicosities of the great saphenous system are present. No significant increase in the formation of edema fluid was found in the patients having ulceration with their varicose veins over the varicose group without ulceration. When a distinction was made between subjects with normal or with incompetent valves of the communicating veins a highly significant increase in tissue fluid formation was found in the latter group. Possible reasons for this are discussed.

\section{CONCLUSIONS}

1. Edema develops more readily in the legs of patients with varicosities than in normal individuals. This tendency is greatly increased when the valves of the communicating veins are incompetent.

2. Studies of the saphenous blood oxygen offer no explanation of this.

\section{BIBLIOGRAPHY}

1. deTakáts, G., Quint, H., Tillotson, B. I., and Crittenden, P. J., The impairment of circulation in the varicose extremity. Arch. Surg., 1929, 18, 671.

2. Blalock, A., Oxygen content of blood in patients with varicose veins. Arch. Surg., 1929, 19, 898.

3. Van Slyke, D.D., and Neill, J. M., The determination of gases in blood and other solutions by vacuum extraction and manometric measurment. I. J. Biol. Chem., 1924, 61, 523.

4. Henderson, L. J., Bock, A. V., Field, H., Jr., and Stoddard, J. L., Blood as a physiocochemical system. II. J. Biol. Chem., 1924, 59, 379.

5. Drury, A. N., and Jones, N. W., Observations upon the rate at which oedema forms when the veins of the human limb are congested. Heart, 1927, $14,55$.

6. Edwards, E. A., and Edwards, J. E., The effect of 
thrombophlebitis on the venous valve. Surg., Gynec. and Obst., 1937, 65, 310.

7. Beecher, H. K., Field, M. E., and Krogh, A., The effect of walking on the venous pressure at the ankle. Skandinav. Arch. f. Physiol., 1936, 73, 133.

8. Beecher, H. K., Adjustment of the flow of tissue fluid in the presence of localized, sustained high venous pressure as found with varices of the great saphenous system during walking. J. Clin. Invest., 1937, 16, 733.

9. Wells, H. S., Personal communication. 1938.

10. Drinker, C. K., Personal communication. 1938.

11. Drinker, C. -K., Field, M. E., Ward, H. K., and Lyons, C., Increased susceptibility to local infection following blockage of lymph drainage. Am. J. Physiol., 1935, 112, 74. 